\title{
ANALISIS HADITS AHKAM MUAMALAH DALAM FATWA DSN MUI TENTANG MURÂBAHAH, SALAM DAN ISTISHNA'
}

\author{
Muhammad Syarif Hidayatullah' \\ Universitas Islam Negeri Antasari Banjarmasin
}

\begin{abstract}
ABSTRAK
Murâbahah, salam dan istishnâ' adalah jenis jual beli yang saat ini dikenal secara konseptual dapat menjadi opsi akad dalam produk lembaga keuangan syariah. DSN-MUI sebagai lembaga yang memiliki otoritas dalam fatwa ekonomi dan keuangan syariahpun sudah merumuskan fatwa tentang tiga jenis jual beli ini, dimana dalam fatwa tersebut terdapat hadits-hadits ahkam muamalah sebagai dasar hukumnya. Tulisan ini bertujuan untuk menganalisis hadits-hadits ahkam muamalah dalam fatwa DSN-MUI tentang murâbahah, salam dan istishnâ' melalui kajian eksistensi (takhrij hadits) dan substansi (telaah makna) hadits. Berdasarkan analisis yang dilakukan, hadits ahkam muamalah dalam fatwa DSN-MUI tentang murâbahah, salam dan istishnâ', secara garis besar menjelaskan tentang asas perjanjian syariah (ar-ridha, al-ibâhah, al-mashlahah), keberkahan dalam jual beli tidak tunai (digolongkan hadits dhaif dalam kategori hadits majhul), pelarangan menunda pembayaran utang bagi yang mampu, legalitas jual beli salam dan legalitas uang muka dalam jual beli (digolongkan hadits dhaif dalam kategori hadits mursal).

Kata Kunci: Hadits Ahkam, Muamalah, Murabahah, Salam, Istishna'
\end{abstract}

\section{ABSTRACT}

Murâbahah, salam and istishnâ' is a type of buying and selling that is currently known conceptually can be an option in the products of Islamic financial institutions. DSN-MUI as an institution that has authority in Islamic economic and finance fatwas has formulated a fatwa on these three types of buying and selling, where in the fatwa there are hadiths ahkam muamalah as the legal basis. This paper aims to analyze the hadiths ahkam muamalah in the fatwa DSN-MUI about murâbahah, salam and istishnâ' through the study of existence (takhrij hadith) and substance (study of meaning) hadith. Based on the analysis conducted, hadith ahkam muamalah in the fatwa DSN-MUI on murâbahah, salam and istishnâ', broadly explains the principle of sharia agreement (ar-ridha, al-ibâhah, almashlahah), blessings in the sale and purchase of cashless (classed as hadith dhaif in the category of hadith majhul), prohibition of delaying the payment of debts for the able, legality of buying and selling salam dan legality of advances in the sale and purchase (classed as hadith dhaif in the category of hadith mursal).

Keywords: Hadith Ahkam, Muamalah, Murabahah, Salam, Istishna'

\section{A. Pendahuluan}

Ruang lingkup pengaturan hubungan dalam Islam telah mencakup perihal ritual (ibadah) dan interaksi sosial (muamalah). ${ }^{1}$ Aturan hukum hubungan tersebut berdasarkan pada teks syariat (wahyu) yaitu nash al-Qur'an dan as-Sunnah yang merupakan sumber hukum utama dalam Islam. Perkara muamalah yang menjurus pada akivitas ekonomi (iqtishâdiyah) dan keuangan (mâliyah) tidak lepas dari konsepsi akad,

${ }^{1}$ Lihat, Aswadi, “Islam sebagai Hasil Hubungan Sosial”, Jurnal Sosiologi Islam, Vol. 2, No.1, (April 2012). 
karena akadlah yang menjadi bagian fundamental dalam legalitas (keabsahan) setiap aktivitas muamalah. ${ }^{2}$ Maka demikian, akad adalah aspek penting yang perlu diperhatikan dalam melaksanakan muamalah.

Salah satu aktivitas muamalah yang menjadi bagian penting di tengah masyarakat dalam rutinitas setiap harinya adalah transaksi jual beli dengan terjadinya pertukaran bermacam-macam barang dengan tingkatan harga yang juga beraneka ragam serta bentuk transaksi yang dapat dilakukan secara tunai maupun tidak tunai (ditangguhkan/kredit). Murâbahah, salam dan istishnâ' menjadi bagian dari transaksi jual beli yang secara konseptual atau teoritis telah memasuki pembahasan terkait akad dan produk keuangan syariah dalam konteks kekinian (kontemporer) pada operasional lembaga keuangan syariah dalam perekonomian modern saat ini. Hal itu dapat kita temukan saat mempelajari literatur-literatur tentang kajian fikih muamalah kontemporer, ekonomi dan keuangan syariah maupun perbankan syariah yang memasukkan tiga jenis jual beli ini dalam substansi kajiannya. ${ }^{3}$

Dewan Syariah Nasional (DSN) yang merupakan bagian dari Majelis Ulama Indonesia (MUI) yang memegang otoritas dan memiliki tugas serta kewenangan dalam mengeluarkan fatwa ekonomi dan keuangan syariah di Indonesia, ${ }^{4}$ telah mengeluarkan fatwa terkait ketentuan hukum akad jual beli murâbahah, salam dan istishnâ'. Fatwa yang dikeluarkan oleh DSN-MUI menjadi landasan pula bagi lembaga keuangan syariah baik itu bank maupun lembaga non bank dalam menjaga prinsip syariahnya. Dalam setiap fatwa yang dikeluarkan, tidak terlepas dari keberadaan sumber hukum Islam yang kedua yaitu hadits. Terdapat hadits-hadits ahkam muamalah yang menjadi landasan hukum bagi keputusan dan ketetapan hukum dalam fatwa tersebut.

Oleh karena itu, artikel ini akan mengkaji hadits-hadits ahkam muamalah yang menjadi landasan hukum eksistensi dan operasionalisasi murâbahah, salam dan istishnâ' yang tertulis dan dicantumkan dalam fatwa DSN-MUI sebagai dasar hukumnya. Analisis hadits ahkam muamalah dalam artikel ini meliputi kajian eksistensi dan substansi hadits dengan sistematika pembahasan hadits akan dibahas satu persatu. Kajian eksistensi hadits yang dimaksud adalah pelacakan sumber hadits melalui takhrij

\footnotetext{
${ }^{2}$ M. Umer Chapra, Islam and The Economic Challenge (USA: The Islamic Foundation and The International Institute of Islamic Thought, 1996).

3 Shalah Ash-Shawi dan Abdullah Al-Mushlih, Fiqih Ekonomi Keuangan Islam, Terj. Ma La yasa' at-Tajira Jahluhu (Jakarta: Darul Haq, 2008).

4 Informasi terkait Dewan Syariah Nasional (DSN) Majelis Ulama Indonesia (MUI) dapat diakses pada https://dsnmui.or.id/.
} 
hadits dan kajian substansi hadits adalah upaya penelaahan makna yang terkandung dalam hadits ahkam muamalah tersebut.

\section{B. Bai' (Jual Beli)}

Jual beli menurut Sayyid Sâbiq adalah pertukaran harta dengan harta atas dasar saling rela atau memindahkan milik dengan ganti yang dapat dibenarkan. ${ }^{5}$ Sedangkan menurut Abû Bakar al Hushnî bahwa jual beli itu adalah pertukaran harta dengan harta yang diterima dengan menggunakan ijab dan kabul dengan cara yang diizinkan oleh syara'. 6

Bai' atau jual beli berbeda dengan ijârah. Walaupun dalam keduanya samasama terjadi pertukaran, tetapi dalam bai' objeknya berupa hak milik sedangkan pada ijârah objeknya adalah hak guna (manfaat). Jadi jual beli merupakan pertukaran yang membawa pada pemindahan kepemilikan sedangkan ijârah tidak memindahkan kepemilikan, melainkan hanya terjadi pemindahan manfaat. Namun disisi lain, ijârah dapat pula diistilahkan dengan terminologi transaksi jual beli yakni dengan sebutan jual beli manfaat baik itu manfaat dari barang maupun jasa.

Legalitas jual beli terdapat dalam QS. al-Baqarah/2: 275

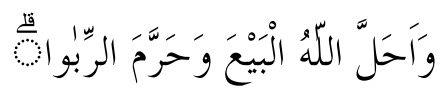

"Padahal Allah telah menghalalkan jual beli dan mengharamkan riba."

Terdapat berbagai macam bentuk transaksi jual beli yang dikenal dalam fikih Islam. Pembagian jual beli tersebut didasarkan pada perspektif yang digunakan dalam hal membaginya.

Tabel 1: Klasifikasi Jual Beli

\begin{tabular}{|c|c|c|c|c|c|}
\hline No & Perpektif & Jual Beli & \multicolumn{3}{|l|}{ Keterangan } \\
\hline \multirow{3}{*}{1} & \multirow{3}{*}{$\begin{array}{l}\text { Objek yang } \\
\text { diperjual } \\
\text { belikan }\end{array}$} & Bai' al mutlaqah & \multicolumn{3}{|c|}{ Pertukaran uang dengan barang } \\
\hline & & Bai' ash sharf & \multicolumn{3}{|c|}{ Pertukaran uang dengan uang } \\
\hline & & Bai' al muqayyadah & \multicolumn{3}{|c|}{ Pertukaran barang dengan barang (barter) } \\
\hline \multirow[b]{2}{*}{2} & \multirow{2}{*}{$\begin{array}{l}\text { Cara } \\
\text { menetapkan } \\
\text { harga } \\
\text { (Standarisasi } \\
\text { harga) }\end{array}$} & Bai' al musâwamah & \multicolumn{3}{|c|}{$\begin{array}{l}\text { Jual beli biasa dimana penjual tidak } \\
\text { menyebutkan harga pokok (modal) dan } \\
\text { keuntungannya, melainkan langsung } \\
\text { menyebutkan harga jual }\end{array}$} \\
\hline & & Bai' al amanah & $\begin{array}{l}\text { Jual beli } \\
\text { dimana } \\
\text { penjual } \\
\text { meyebutkan } \\
\text { harga pokok }\end{array}$ & & $\begin{array}{l}\text { Jual beli } \\
\text { dengan } \\
\text { menyebutkan } \\
\text { harga pokok } \\
\text { (modal) dan }\end{array}$ \\
\hline
\end{tabular}

\footnotetext{
${ }^{5}$ Sayyid Sâbiq, Fiqh as-Sunnah, vol. 3 (Kairo: al-Fath lil l’lâm al-‘Arabî, 2004), 898.

6 Taqiyuddîn Abû Bakr bin Muhammad al Hushnî al Husainî, Kifâyah al-Akhyâr (Damaskus: Dâr al-Basyâir, 2001), 279.
} 


\begin{tabular}{|c|c|c|c|c|c|}
\hline & & & (modal) & & $\begin{array}{l}\text { keuntungan } \\
\text { yang } \\
\text { dinginkan }\end{array}$ \\
\hline & & & & $\begin{array}{l}\text { Muwâdha'ah } \\
\text { atau } \\
\text { wadhi'ah }\end{array}$ & $\begin{array}{l}\text { Jual beli } \\
\text { dibawah } \\
\text { harga modal } \\
\text { dengan } \\
\text { jumlah } \\
\text { kerugian } \\
\text { yang } \\
\text { diketahui }\end{array}$ \\
\hline & & & & Tauliyah & $\begin{array}{l}\text { Jual beli } \\
\text { dengan harga } \\
\text { modal (tanpa } \\
\text { keuntungan } \\
\text { dan } \\
\text { kerugian) }\end{array}$ \\
\hline & & Bai' al muzâyadah & $\begin{array}{l}\text { Jual beli de } \\
\text { dan para pen } \\
\text { penawar te } \\
\text { pembeli. Dise }\end{array}$ & $\begin{array}{l}\text { gan penawara } \\
\text { hbeli berlomba } \\
\text { rtinggi te } \\
\text { but juga jual b }\end{array}$ & $\begin{array}{l}\text { dari penjual } \\
\text { nenawar, lalu } \\
\text { ilih sebagai } \\
\text { li lelang. }\end{array}$ \\
\hline & & Bai' al munâqadhah & $\begin{array}{l}\text { Kebalikannya } \\
\text { jual beli den } \\
\text { membeli } \\
\text { tertentu da } \\
\text { menawarkan } \\
\text { pembeli aka } \\
\text { menawarkan }\end{array}$ & $\begin{array}{l}\text { dari Bai' al mu } \\
\text { gan penawaran } \\
\text { arang denga } \\
\text { n para pen } \\
\text { daganganny } \\
\text { membeli dar } \\
\text { harga termural }\end{array}$ & $\begin{array}{r}\text { sâyadah, yaitu } \\
\text { sembeli untuk } \\
\text { sal berlomba } \\
\text { penjual yang }\end{array}$ \\
\hline & & $\begin{array}{l}\text { Jual beli tunai (bai' } \\
\text { naqdan) }\end{array}$ & $\begin{array}{l}\text { Jual beli } \\
\text { penyerahan } \mathrm{k}\end{array}$ & $\begin{array}{l}\text { dengan pen } \\
\text { arang secara la }\end{array}$ & $\begin{array}{l}\text { Jayaran dan } \\
\text { ggsung }\end{array}$ \\
\hline & & & $\begin{array}{l}\text { Jual beli } \\
\text { dengan } \\
\text { pembayaran }\end{array}$ & $\begin{array}{l}\text { Pembayaran } \\
\text { waktu yang te } \\
\text { dikemudian } \\
\text { di satu waktu }\end{array}$ & $\begin{array}{l}\text { penuh pada } \\
\text { ah ditentukan } \\
\text { ari (sekaligus }\end{array}$ \\
\hline & Cara & & $\begin{array}{l}\text { tertunda } \\
\text { (bai' } \\
\text { muajjal) }\end{array}$ & $\begin{array}{l}\text { Pembayaran } \\
\text { angsuran/cici } \\
\text { taqsith) }\end{array}$ & $\begin{array}{r}\text { dengan } \\
\text { (bai' }\end{array}$ \\
\hline 3 & $\begin{array}{l}\text { pembayaran } \\
\text { atau } \\
\text { transaksi } \\
\text { yang } \\
\text { dilakukan }\end{array}$ & $\begin{array}{l}\text { Jual beli tidak } \\
\text { tunai/tangguh/tunda }\end{array}$ & $\begin{array}{l}\text { Jual beli } \\
\text { dengan } \\
\text { penyerahan }\end{array}$ & $\begin{array}{l}\text { Bai' as salam } \\
\text { ketika pemb } \\
\text { tunai di muk } \\
\text { yang dipes } \\
\text { produk pert } \\
\text { barang yang a } \\
\text { kemudian }\end{array}$ & $\begin{array}{l}\text { yaitu jual beli } \\
\text { li membayar } \\
\text { atas barang } \\
\text { (biasanya } \\
\text { hian) dengan } \\
\text { an diserahkan }\end{array}$ \\
\hline & & & tertunda & $\begin{array}{l}\text { Bai' al Istish } \\
\text { beli dima } \\
\text { membayar } \\
\text { bertahap ata } \\
\text { dipesan (bia }\end{array}$ & $\begin{array}{lr}\hat{a}^{\prime} \text { yaitu jual } \\
\text { a pembeli } \\
\text { tunai atau } \\
\text { barang yang } \\
\text { anya produk }\end{array}$ \\
\hline
\end{tabular}




\begin{tabular}{|l|l|l|l|}
\hline & & $\begin{array}{l}\text { manufaktur) dengan } \\
\text { spesifikasinya yang harus } \\
\text { diproduksi dan diserahkan } \\
\text { kemudian }\end{array}$ \\
& $\begin{array}{l}\text { Jual beli dengan pembayaran dan } \\
\text { penyerahan barang sama-sama tertunda } \\
\text { atau jual beli utang dengan utang (bai' al } \\
\text { kâli bil kâli atau bai' dayn bid dain) }\end{array}$ \\
\hline
\end{tabular}

\section{Murâbahah, Salam dan Istishnâ'}

Murâbahah yaitu menjual barang sesuai dengan harga pembelian dengan menambahkan keuntungan tertentu. ${ }^{8}$ Jadi akad murâbahah adalah akad jual beli dengan menyebutkan harga perolehan barang dan keuntungan yang disepakati. Pembayaran dalam jual beli murâbahah dapat dilakukan secara tunai dimuka, diangsur, maupun ditangguhkan. Bentuk akad murâbahah dapat dibagi menjadi dua bentuk, yakni murâbahah biasa (tanpa pesanan) dan murâbahah lil amir bi asy-syirâ' (dengan pesanan)

\section{Murâbahah biasa (tanpa pesanan)}

Murâbahah biasa yaitu akad murâbahah saat penjual memasarkan dan menawarkan barangnya kepada pembeli dengan menyebutkan harga perolehan barang tersebut dan keuntungan yang telah disepakati diantara keduanya. Jadi dalam murâbahah seperti ini hanya melibatkan dua pihak yaitu penjual dan pembeli (bentuk sederhana). Tanpa dipesanpun, stok barang telah tersedia.

2. Murâbahah lil âmir bi asy-syirâ'

Murâbahah lil amir bi asy-syirâ' adalah istilah yang tidak ditemukan dalam fikih klasik. Istilah ini baru dikenal dalam fikih kontemporer yang diperkenalkan oleh Sâmî Hamûd dalam disertasinya yang juga telah dibukukan berjudul Tathwîr al-A'mâl alMashrafiyyah bi Mâ Yattafiq asy-Syar'iyyah al-Islâmiyyah. ${ }^{9}$

Murâbahah lil amir bi asy-syirâ' atau murâbahah kepada pemesan pembelian, yaitu akad murâbahah yang terjadi ketika ada yang memesan barang. Jadi dalam hal ini terdapat tiga pihak terkait, yakni supplier, reseller dan pemesan pembelian. Murâbahah seperti inilah yang diterapkan di Lembaga Keuangan Syariah (LKS), dikarenakan LKS bukanlah pihak yang menyimpan stok barang. Pada transaksi lembaga

\footnotetext{
${ }^{7}$ Para Ulama sepakat (konsensus) bahwa transaksi bai' al kâli bil kâli adalah transaksi terlarang. Maka hal ini telah menjadi ijma' Ulama.

${ }^{8}$ Wahbah az Zuhailî, al-Fiqh al-Islâmî wa Adillatuh, vol. 4 (Damaskus: Dâr al-Fikr, 1985), 703.

9 Sâmî Hasan Ahmad Hamûd, Tathwîr al-A'mâl al-Mashrafiyyah bi Mâ Yattafiq asy-Syar'iyyah al-Islâmiyyah (Dubai: Mathba'ah asy-Syarq wa Maktabatihâ, 1982).
} 
keuangan, maka yang berperan dalam transaksi ini adalah pihak LKS sebagai penjual, nasabah (pemesan barang) sebagai pembeli, dan supplier sebagai pemasok barang kepada LKS. ${ }^{10}$ Dengan demikian pembelian barang oleh LKS dilakukan ketika ada pemesanan barang dari nasabah.

Selanjutnya akad jual beli salam adalah menjual sesuatu yang tidak dilihat zatnya, hanya ditentukan dengan sifat, barang itu ada didalam pengakuan. Kemudian didefinisikan lagi sebagai jual beli utang dari pihak penjual dan kontan dari pihak pembeli karena uangnya telah dibayarkan sewaktu akad. ${ }^{11}$ Akad salam disebut juga dengan istilah salaf. Penduduk Hijaz menamakan akad pemesanan barang dengan istilah salam, sedangkan penduduk Irak menyebutnya salaf.

Dengan demikian akad salam merupakan akad jual beli dengan pembayaran dimuka dan penyerahan barang dikemudian hari (ditangguhkan) atau bisa diartikan secara lebih rinci terkait dengan operasionalnya yakni jual beli pesanan dengan pembayaran harga lebih dulu ketika akad dengan harga, kualitas dan kuantitas barang serta tempo dan tempat penyerahan yang jelas. Akad salam dalam produk lembaga keuangan syariah khususnya bank syariah dapat diterapkan pada pembiayaan sektor pertanian atau pembiayaan agrobisnis.

Apabila LKS menerapkan produk pembiayaan berpola akad salam, maka operasionalnya berbentuk akad salam paralel, yakni LKS terlebih dahulu memiliki nasabah yang telah bersedia membeli hasil tani yang diperoleh dari petani. Dengan begitu dalam transaksi ini ada tiga pihak, yakni LKS, nasabah pembeli hasil tani dan nasabah petani atau penyedia hasil tani. LKS bertindak sebagai pembeli sedangkan nasabah petani sebagai penjual produk hasil pertanian. Mengingat LKS tidak menjadikan barang yang dibeli atau dipesannya sebagai persediaan (inventory), maka dimungkinkan bagi LKS untuk melakukan akad salam kepada pihak ketiga (pembeli kedua) seperti Bulog, pedagang pasar induk, eksportir atau industri pengolah. ${ }^{12}$ Mekanisme seperti inilah yang dinamakan salam paralel dengan LKS melakukan dua akad salam dengan syarat akad kedua terpisah dari, dan tidak berkaitan dengan akad pertama.

\footnotetext{
10 Yenti Afrida, “Analisis Pembiayaan Murabahah di Perbankan Syariah," JEBI (Jurnal Ekonomi dan Bisnis Islam) 1, no. 2 (1 Desember 2016): 162, https://doi.org/10.15548/jebi.v1i2. 32.

11 Sulaiman Rasjid, Fiqh Islam (Bandung: Sinar Baru Algesindo, 1998), 294-295.

12 Widiana Widiana dan Arna Asna Annisa, "Menilik Urgensi Penerapan Pembiayaan Akad Salam pada Bidang Pertanian di Lembaga Keuangan Syariah di Indonesia," Muqtasid: Jurnal Ekonomi dan Perbankan Syariah 8, no. 2 (2017): 96-97, https://doi.org/10.18326/muqtasid.v8i2.88-101.
} 
Selain akad jual beli murâbahah dan salam, dikenal pula akad istishnâ' dalam kajian fikih muamalah, akad ini didefinisikan sebagai akad meminta seseorang untuk membuat sebuah barang tertentu dalam bentuk tertentu. ${ }^{13}$ Akad istishnâ' sedikit menyerupai akad ijârah. Dalam akad istishnâ' bahan baku pembuatan barang berasal dari si pembuat barang, kalau bahan baku berasal dari si pemesan, maka ini bukan lagi akad istishnâ', melainkan akad ijârah yakni menyewa jasa seseorang. Skema istishnâ' yang diterapkan dalam produk pembiayaan LKS dapat menerapkan konsep istishnâ' paralel, yaitu suatu bentuk akad istishnâ' antara pemesan (pembeli/mustashni') dengan penjual (pembuat/shani'), kemudian untuk memenuhi kewajibannya kepada mustashni', penjual memerlukan pihak lain sebagai shani'.

Produk pembiayaan berpola akad istishnâ' dalam praktik di LKS dapat diterapkan pada pembiayaan konstruksi. Pembiayaan konstruksi yang dimaksud seperti pembiayaan hunian syariah baik itu berupa rumah, rumah susun (rusun), rumah toko (ruko), apartemen dan lain-lain yang objeknya dalam proses pembangunan. Selain itu dapat pula diaplikasikan pada pembiayaan manufaktur, yaitu pembiayaan pada objek barang perlu diproduksi atau dibuat terlebih dahulu (dari bahan mentah jadi bahan jadi/olahan) seperti barang-barang kerajinan, pakaian, properti rumah, alat-alat kantor dan lain sebagainya.

D. Analisis Hadits-hadits Ahkam Muamalah dalam Fatwa DSN-MUI tentang Jual Beli Murâbahah, Salam dan Istishnâ'

Pada bagian ini akan dibahas hadits-hadits ahkam muamalah yang terdapat dalam fatwa DSN-MUI tentang jual beli murâbahah, salam dan istishnâ' yang akan dikaji satu persatu.

\section{Hadits Ahkam Muamalah ke-1}

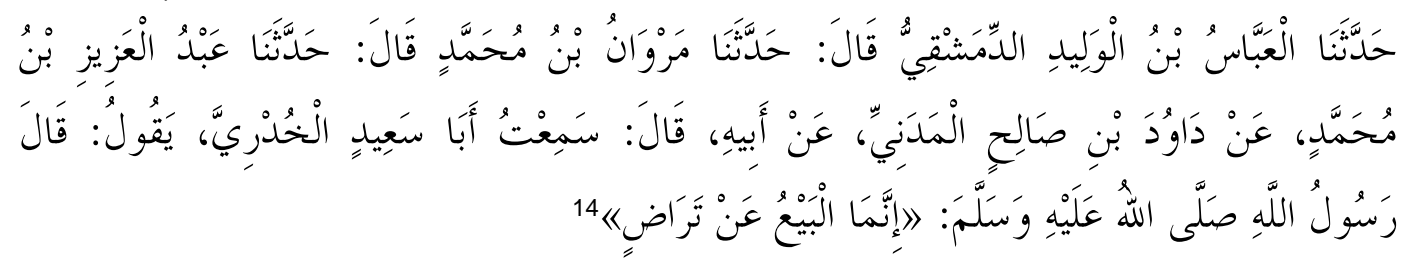

Telah menceritakan kepada kami al Abbas bin al Walid ad Dimasyqi berkata, telah menceritakan kepada kami Marwan bin Muhammad berkata, telah menceritakan kepada

\footnotetext{
${ }^{13}$ az Zuhailî, al-Fiqh al-Islâmî wa Adillatuh, 4: 631.

14 Abû Abdullah Muhammad Bin Yazîd bin Mâjah al Qazwînî, Sunan Ibnu Mâjah, vol. 2 (Kairo: Dâr al-Ihya' alKutub al-'Arabiyah, t.t.), 737; Abû Bakar Ahmad bin al Husain bin "Alî bin 'Abdullah bin Mûsa al Khusraujirdî al Baihaqî, as-Sunan al-Kubrâ, vol. 6 (Beirut: Dâr al-Kutub al-'Ilmiyah, 2003), 29; Abû Hâtim Muhammad bin Hibbân bin Ahmad bin Hibbân bin Mu'adz bin Ma'bad at Tamîmî, Shahîh Ibnu Hibbân, vol. 11 (Beirut: Muassasah ar-Risâlah, 1993), 340.
} 
kami Abdul Aziz bin Muhammad dari Dawud bin Shalih al Madini dari Bapaknya berkata; aku mendengar Abu Sa'id al Khudri, ia berkata, "Rasulullah shallallahu 'alaihi wasallam bersabda: "Sesungguhnya jual beli itu berlaku dengan saling ridha (suka sama suka)."

Hadits di atas terdapat dalam fatwa DSN-MUI tentang murâbahah dan salam. Hadits ini diriwayatkan oleh Imam Baihaqî dan Ibnu Mâjah serta dinilai shahih oleh Ibnu Hibbân. Sanad pada hadits di atas merupakan sanad dalam hadits riwayat Ibnu Mâjah.

Berkenaan dengan substansi dari hadits di atas, maka pembahasannya dapat dimulai dengan mengenal apa itu ridha terlebih dahulu. Ridha secara bahasa berasal dari bahasa Arab radhiya yang artinya senang hati (rela). Ridha menurut syariah adalah menerima dengan senang hati atas segala yang diberikan Allah SWT baik berupa hukum (peraturan-peraturan) maupun ketentuan-ketentuan yang telah ditetapkan-Nya. Pengertian ini adalah pengertian dalam perspektif fikih ibadah atau penjabaran atas dasar interaksi manusia kepada Allah SWT (habluminallah). Sedangkan dalam perspektif fikih muamalah atau penjabaran atas dasar interaksi manusia dengan manusia (habluminannas), maka ridha diartikan menerima dan menyetujui dengan suka rela (tanpa paksaan) transaksi yang dilaksanakan antara seseorang dengan orang lain pada akad yang dilangsungkan.

Terdapat beberapa rukun dalam sebuah akad yang dilangsungkan yakni:

Subjek akad; (2) Objek akad; dan (3) Shigat (ijab kabul). Keberadaan ijab dan kabul dapat disebut sebagai indikator keridhaan. Maksud diadakannya ijab dan kabul untuk menunjukkan adanya suka rela timbal balik terhadap perikatan yang dilakukan oleh dua pihak yang bersangkutan. Dapat disimpulkan bahwa akad terjadi diantara dua pihak dengan suka rela yang pada akhirnya berimplikasi menimbulkan kewajiban atas masing-masing secara timbal balik. Maka dari itu sudah jelas pihak yang menjalin ikatan perlu memperhatikan terpenuhinya hak dan kewajiban masing-masing pihak tanpa ada pihak yang terlanggar haknya. ${ }^{15}$

Suatu jual beli tidak sah apabila tidak terpenuhi syarat sahnya jual beli dan salah satu syaratnya adalah syarat saling rela (keridhaan) antara kedua belah pihak. Kerelaan antara kedua belah pihak untuk melakukan transaksi merupakan syarat mutlak keabsahannya. ${ }^{16}$ Setiap transaksi dalam Islam harus didasarkan pada prinsip keridhaan atau kerelaan antara kedua belah pihak (sama-sama ridha). Mereka harus mempunyai informasi yang sama (complete information) sehingga tidak ada yang

\footnotetext{
15 Fathurrahman Azhari, Qawaid Fiqhiyyah Muamalah (Banjarmasin: Lembaga Pengembangan Kualitas Umat, 2014), 202-203.

${ }^{16}$ Mardani, Fiqih Ekonomi Syariah: Fiqih Muamalah (Jakarta: Kencana, 2012), 104.
} 
bersifat unknown to one party (keadaaan dimana salah satu pihak tidak mengetahui informasi yang diketahui pihak lain, ini disebut juga assymetric information). Unknown to one party dalam bahasa fikihnya disebut tadlis, dan dapat terjadi dalam 4 (empat) hal, yakni dalam kuantitas, kualitas, harga dan waktu penyerahan. ${ }^{17}$

Keridhaan dari pihak yang bertransaksi merupakan suatu asas yang penting untuk diterapkan dalam sebuah akad (perjanjian/kontrak). Dengan bekal keridhaan dari kedua belah pihak yang bertransaksi maka akan tercapai kesepakatan yang murni dalam akad tersebut. Syamsul Anwar pada konteks asas perjanjian dalam hukum Islam, menyebutkan keberadaan asas konsensualisme (mabda ar-radha'iyyah) yang merupakan suatu asas yang menyatakan untuk terciptanya suatu perjanjian cukup dengan tercapainya kata sepakat antara pihak tanpa perlu dipenuhinya formalitasformalitas tertentu. ${ }^{18}$ Kompilasi Hukum Ekonomi Syariah menyebutkan pada pasal 21 tentang asas-asas akad yang salah satunya disebut dengan asas ikhtiyari/sukarela yang bermakna bahwa setiap akad dilakukan atas kehendak para pihak, terhindar dari keterpaksaan karena tekanan salah satu pihak atau pihak lain. ${ }^{19}$ Kemudian Burhanuddin Susanto menyebutkan bahwa salah satu asas dalam kontrak syariah adalah asas ar-ridhâ (asas keridhaan) yang menyatakan bahwa segala transaksi yang dilakukan harus berdasarkan keridhaan antara masing-masing pihak. ${ }^{20}$ Jadi Apabila $^{2}$ dalam melakukan transaksi keuangan walaupun itu adalah jual beli yang halal, namun tidak terpenuhi asas ini, maka sama artinya dengan memakan harta dengan cara yang bathil.

Allah SWT berfirman dalam QS. an-Nisâ/4: 29

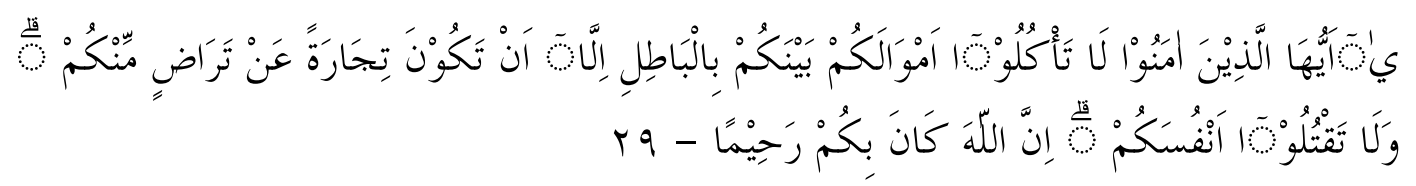

"Hai orang-orang yang beriman, janganlah kamu saling memakan harta sesamamu dengan jalan yang batil, kecuali dengan jalan perniagaan yang Berlaku dengan suka sama-suka di antara kamu. dan janganlah kamu membunuh dirimu; Sesungguhnya Allah adalah Maha Penyayang kepadamu."

Kaidah fikih terkait dengan prinsip suka sama suka (saling ridha) dalam bermuamalah antara lain:

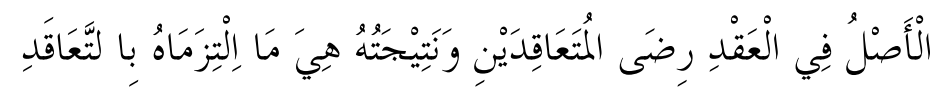

\footnotetext{
${ }^{17}$ Adiwarman A. Karim, Bank Islam: Analisis Fiqih dan Keuangan (Jakarta: RajaGrafindo Persada, 2008$), 31$.

18 Syamsul Anwar, Hukum Perjanjian Syariah: Studi tentang Teori Akad dalam Fikih Muamalat (Jakarta: RajaGrafindo Persada, 2010), 87.

19 Pusat Pengkajian Hukum Islam dan Masyarakat Madani, Kompilasi Hukum Ekonomi Syariah (Depok: Kencana, 2009), 20.

20 Burhanuddin Susanto, Hukum Kontrak Syariah (Yogyakarta: BPFE, 2009), 45.
} 
"Hukum asal pada akad adalah keridhaan kedua belah pihak yang mengadakan akad, hasilnya apa yang saling diiltizamkan oleh perakadan itu".

Kemudian kaidah turunannya:

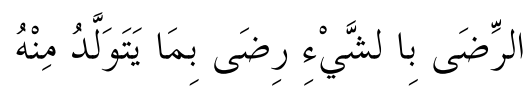
padanya"

"Keridhaan dengan sesuatu adalah ridha dengan akibat yang terjadi dari

\section{Hadits Ahkam Muamalah ke-2}

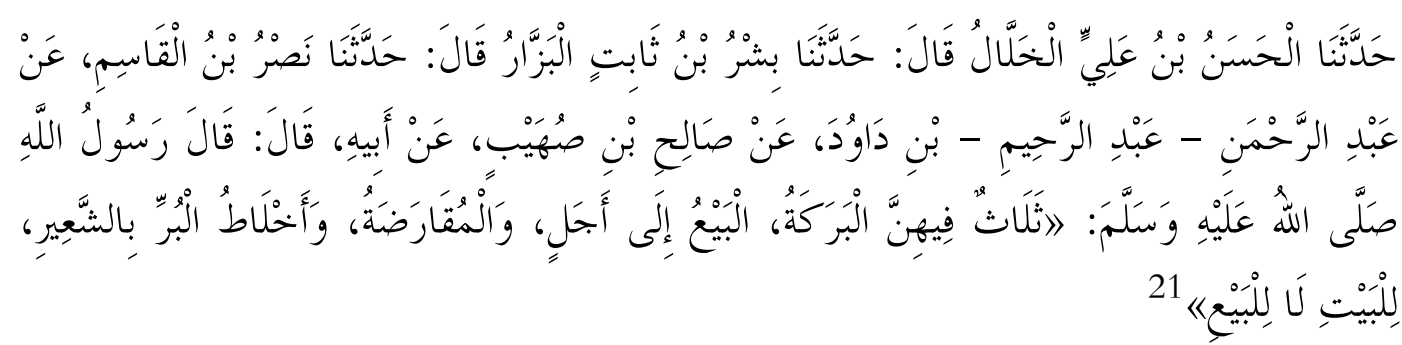

Telah menceritakan kepada kami al Hasan bin Ali al Khallal berkata, telah menceritakan kepada kami Bisyr bin Tsabit al Bazzar berkata, telah menceritakan kepada kami Nashr bin al Qasim dari 'Abdurrahman bin Dawud dari Shalih bin Shuhaib dari Bapaknya ia berkata, "Rasulullah shallallahu 'alaihi wasallam bersabda: "Ada tiga hal yang mengandung berkah: jual beli tidak secara tunai, muqaradhah (mudharabah), dan mencampur gandum dengan jewawut untuk keperluan rumah tangga, bukan untuk dijual."

Hadits di atas terdapat dalam fatwa DSN-MUI tentang murâbahah. Hadits ini merupakan hadits riwayat Ibnu Mâjah dalam Sunan Ibnu Mâjah. Hadits ini secara tersurat menunjukkan makna bahwa adanya berkah dalam transaksi keuangan berupa jual beli tidak tunai (kredit) dan muqâradhah atau disebut pula mudhârabah (akad kerja sama bagi hasil) dalam istilah yang lebih umum dan populer dikenal pada literatur-literatur fikih muamalah kontemporer dan juga pada akad dan produk lembaga keuangan syariah serta istilah yang digunakan oleh Dewan Syariah Nasional Majelis Ulama Indonesia (DSN-MUI).

Muhammad Fuad Abdul Baqi mengomentari hadits di atas dengan menyatakan bahwa di dalam sanadnya yakni Shalih bin Shuhaib itu majhul. ${ }^{22}$ Hadits majhul merupakan bagian dari hadits dhaif dengan kedhaifan dari segi sanad berupa cacat pada perawinya yakni hadits dengan salah seorang perawinya tidak diketahui identitasnya karena tidak dikenal. ${ }^{23}$ Maksudnya adalah hadits yang di dalam sanadnya terdapat seorang perawi yang tidak dikenal jati dirinya atau dikenal

\footnotetext{
21 al Qazwînî, Sunan Ibnu Mâjah, 2: 768.

22 al Qazwînî, 2: 768. Kitab Sunan Ibnu Mâjah ditahqiq oleh Muhammad Fuad Abdul Baqi.

23 M. Ma'shum Zein, Ilmu Memahami Hadits Nabi: Cara Praktis Menguasai Ulumul Hadits dan Musthalah Hadits (Yogyakarta: Pustaka Pesantren, 2016), 111.
} 
orangnya. Jadi tidak dikenal identitas atau sifat-sifat keadilan dan kedhabitannya. Walaupun demikian, bukan berarti ketetapan transaksi dalam hadits tersebut dilarang, melainkan jual beli kredit dan mudhârabah hukumnya adalah boleh asalkan tidak ada unsur-unsur terlarang di dalamnya sebab hukum asal muamalah adalah boleh selama tidak ada dalil yang melarangnya. Selain itu pula tidaklah mengapa menggunakan hadits dhaif sebagai rujukan dalam menguatkan fadhâ'il a'mal (keutamaan amal) selama hadits tersebut kedhaifannya tidaklah sampai pada derajat maudhu' (palsu) dan sejalan (tidak bertentangan) dengan hadits shahih atau dapat dikatakan masih bernaung di bawah hadits shahih.

Hadits lain yang terkait seperti hadits riwayat Bukhari berikut:

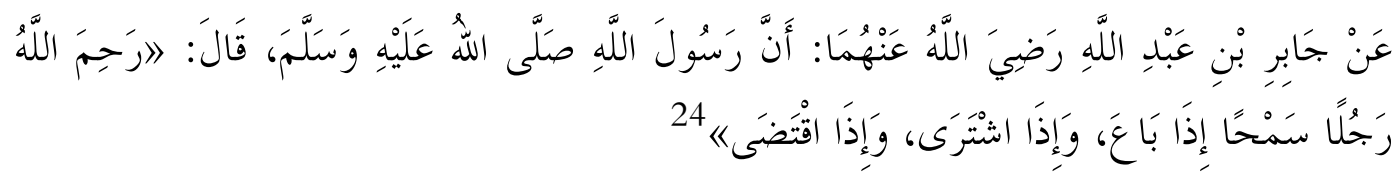

Dari Jabir bin 'Abdillah ra: Sesungguhnya Rasulullah SAW bersabda,"Semoga Allah merahmati seseorang yang memudahkan (memberi kelapangan) ketika menjual dan membeli, dan ketika menagih haknya dari orang lain."

Dalam hadits riwayat at Tirmidzi berbunyi:

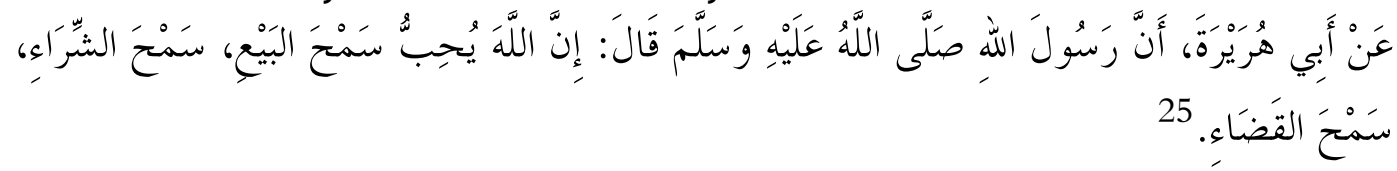

Dari Abu Hurairah, Bahwasanya Rasulullah SAW bersabda, "Sesungguhnya Allah mencintai orang yang memberi kemudahan dalam menjual, memberi kemudahan tatkala membeli, dan kemudahan dalam memutuskan perkara.

Dibolehkan mengamalkan hadits dhaif dalam hal fadhâil a'mal, zuhud, nasehat, kisah-kisah, selain hukum syariat dan akidah, selama hadits tersebut bukan hadits maudhu' (palsu). Ada haditst dhaif yang bisa diamalkan, seperti haditst dhaif yang yang disebabkan terputusnya sanad, atau karena majhul, dan yang lain yang mana kedhaifan haditst tersebut dikategorikan ringan. Haditst dhaif yang tidak bisa diamalkan seperti haditst dhaif yang disebabkan adanya perawi yang banyak salah dan lupanya (munkar), atau adanya perawi yang dituduh berdusta (matruk), atau perawi yang pendusta (maudhu'). ${ }^{26}$

${ }^{24}$ Abû 'Abdullah Muhammad bin Ismâ'îl bin Ibrahim bin al Mughîrah bin Bardizbah al Ju'fi al Bukhârî, Shahih al-Bukhârî, vol. 3 (Beirut: Dâr Thauq an-Najah, 2001), 57.

${ }^{25}$ Abû 'îsâ Muhammad bin 'îsâ bin Saurah bin Mûsa bin adh Dhahâk at Tirmidzî, Sunan at-Tirmidzî, vol. 2 (Beirut: Dar al-Gharb al-Islami, 1998), 600.

26 Mohammad Maulana Nur Kholis, "Hukum Mengamalkan Hadist Dhaif Dalam Fadhail A'mal: Studi Teoritis Dan Praktis," Al-Tsiqoh : Jurnal Ekonomi Dan Dakwah Islam 1, no. 2 (2016): 37-39. 
Ibnu Hajar al-Asqalani menyebutkan tiga syarat terhadap hadits dhaif yang boleh digunakan dalam fadhâil a'mal, yakni: (1) kelemahan haditsnya tidak terlalu parah, sehingga orang yang bersendirian dalam meriwayatkannya di antara para pendusta dan orang yang tertuduh berdusta, atau orang yang sangat parah kesalahannya tidak masuk kriteria dalam syarat ini; (2) hendaknya termasuk dalam prinsip umum yang diamalkan, sehingga tidak termasuk di dalamnya sesuatu yang diada-adakan; dan (3) bahwa ketika mengamalkannya yang bersangkutan tidak meyakini kepastiannya sebagai hadits nabi SAW, agar tidak dinisbatkan kepadanya apa yang tidak disabdakannya, tetapi ia hanya yakin akan kemungkinannya saja. ${ }^{27}$

Namun demikian, karena ini adalah produk hukum berupa fatwa yang berisi putusan dan penetapan suatu hukum, maka sebaiknya dan sudah seharusnya hadits yang dijadikan sebagai landasan dalam kerangka istinbath hukumnya adalah hadits shahih atau paling tidak hadits dengan derajat hasan.

\section{Hadits Ahkam Muamalah ke-3}

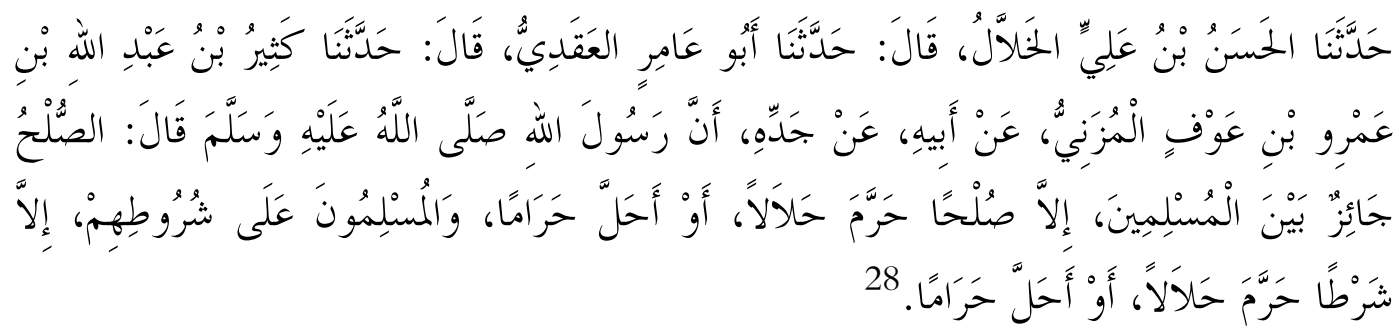

Telah menceritakan kepada kami al Hasan bin Ali al Khallal, telah menceritakan kepada kami Abu Amir al 'Aqadi, telah menceritakan kepada kami Katsir bin Abdullah bin Amru bin 'Auf Al Muzani dari ayahnya dari kakeknya bahwa Rasulullah shallallahu 'alaihi wasallam bersabda: "Perdamaian diperbolehkan di antara kaum muslimin kecuali perdamaian yang mengharamkan yang halal atau menghalalkan yang haram. Dan kaum muslimin boleh menentukan syarat kecuali syarat yang mengharamkan yang halal atau menghalalkan yang haram."

Hadits di atas terdapat dalam fatwa DSN-MUI tentang murâbahah, salam dan istishnâ'. Teks hadits di atas secara lengkap ditemukan dalam Sunan at Tirmidzî dan at Tirmidzî menyatakan bahwa hadits ini adalah hadits hasan shahih. Hadits yang serupa juga ditemukan dalam al-Mustadrak 'alâ ash-Shahîhain yang disusun oleh al Hâkim. ${ }^{29}$ Imam Ahmad dalam musnadnya hanya meriwayatkan pada kalimat الصَّلْحُ جَائزٌ بَيْنَ

27 Hading Hading, “Hadits Ḍa'īf (Sebab-Sebab Ke-Ḍa'īf-an dan Ke-Hujjah-annya Menurut Ulama Ahli Hadits)," Shaut al Arabiyyah 5, no. 1 (2017): 33.

${ }^{28}$ Abû 'îsâ Muhammad bin 'îsâ bin Saurah bin Mûsa bin adh Dhahâk at Tirmidzî, Sunan at-Tirmidzî, vol. 3 (Beirut: Dar al-Gharb al-Islami, 1998), 28.

${ }^{29}$ Abû 'Abdullah Muhammad bin 'Abdullah al Hâkim an Naisâbûrî, al-Mustadrak 'alâ ash-Shahîhain, vol. 4 (Beirut: Dâr al-Kutub al-‘Ilmiyah, 1990), 113. 


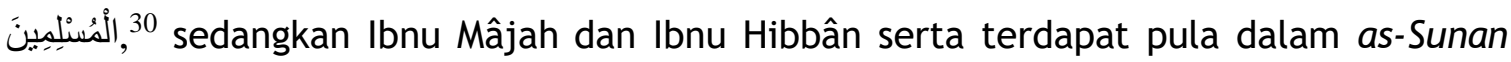

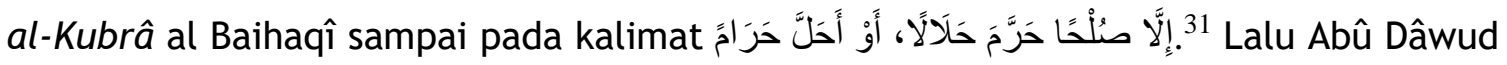
hingga kalimat 32 32

Hadits ini menjelaskan bahwa seluruh macam perjanjian perdamaian antara kaum muslimin itu boleh dilakukan, selama tidak menyebabkan pelakunya terjerumus ke dalam suatu yang diharamkan atau melanggar syariat. Bahwasanya pula hukum asal dari persyaratan-persyaratan yang telah disepakati oleh kaum Muslimin dalam berbagai akad yang dilaksanakan adalah diperbolehkan. Karena mengandung maslahat dan tidak ada larangan syariat tentang hal itu. Tentunya, selama syarat-syarat itu tidak membawa pelakunya terjerumus kedalam suatu yang diharamkan. Apabila mengandung unsur haram sehingga bisa membawa pelakunya terjerumus dalam perkara yang haram maka syarat-syarat tersebut tidak diperbolehkan. Jika dikaitkan dengan perjanjian syariah secara umum, maka hadits ini menunjukkan keberadaan asas al-ibâhah (kebolehan), merupakan asas umum hukum Islam dalam bermuamalah termasuk dalam melakukan akad di dalamnya, sebab hukum asal muamalah adalah boleh atau halal. ${ }^{33}$ Kebolehan ini dibatasi terhadap keberadaan dasar hukum yang melarangnya. Hal ini berarti bahwa Islam memberi kesempatan luas kepada yang berkepentingan untuk mengembangkan bentuk dan macam transaksi baru sesuai dengan perkembangan zaman dan kebutuhan masyarakat. Kaidah fikih yang dibangun atas dasar hadits ini yakni:

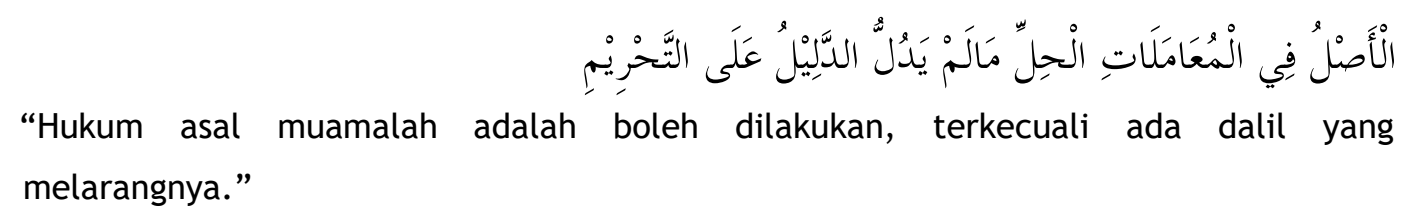

${ }^{30}$ Abû 'Abdullah Ahmad bin Muhammad bin Hanbal bin Hilâl bin bin Asad asy Syaibânî, Musnad Ahmad, vol. 14 (Beirut: Muassasah ar-Risâlah, 2001), 389.

31 at Tamîmî, Shahîh Ibnu Hibbân, 11: 488; al Qazwînî, Sunan Ibnu Mâjah, 2: 788; al Baihaqî, as-Sunan alKubrâ, 6: 107.

${ }^{32}$ Abû Dâwud Sulaimân bin al Asy’ats bin Ishâq bin Basyîr bin Syidâd bin 'Amrû al-Azdî as Sijistânî, Sunan Abû Dâwud, vol. 3 (Beirut: Maktabah al-'Ashriyah, t.t.), 304.

33 Yûsuf al Qaradhâwî, al-Qawâ'id al-Hâkimah li Fiqh al-Mu'âmalât (Kairo: Dâr asy-Syurûq, 2010), h. 5; Muhammad Nâshiruddîn al Albânî, Irwâ' al-Ghalîl fî̀ Takhrîj Ahâdîts Manâr as-Sabîl, vol. 5 (Beirut: alMaktab al-Islâmî, 1985), h. 294; Abû 'Abdurrahmân 'Abdullah bin 'Abdurrahmân bin Shâlih bin Hammad bin Muhammad bin Hammad al-Bassâm, Taisîr al- 'Allâm Syarah 'Umdah al-Ahkâm (Beirut: Maktabah at-Tâbi'în, 2006), h. 449. 


\section{Hadits Ahkam Muamalah ke-4}

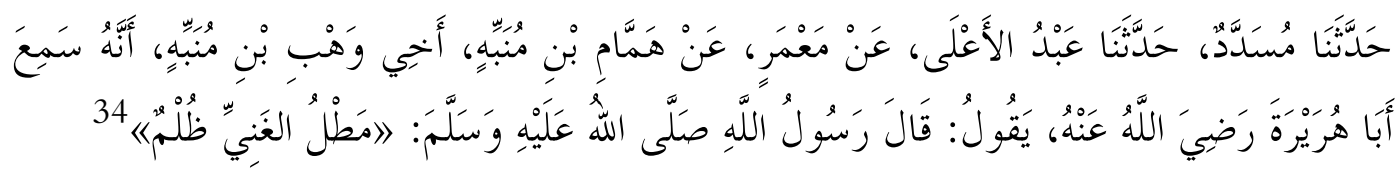

Telah menceritakan kepada kami Musaddad telah menceritakan kepada kami 'Abdul A'la dari Ma'mar dari Hammam bin Munabbih, saudaranya Wahb bin Munabbih] bahwa dia mendengar Abu Hurairah ra berkata; Nabi shallallahu 'alaihi wasallam bersabda: "Menunda-nunda (pembayaran) yang dilakukan oleh orang mampu adalah suatu kezaliman."

Hadits di atas terdapat dalam fatwa DSN-MUI tentang murâbahah dan salam. Hadits ini diriwayatkan oleh jama'ah yakni Imam Bukhârî, Muslim, Abû Dâwud, an Nasâ'̂̂, Ibnu Mâjah dan at-Tirmidzî. Jadi hadits ini ditemukan dalam kitab-kitab hadits yang termasuk dalam kutub as-Sittah yakni Shahih al-Bukhârî , Shahîh Muslim, Sunan Abû Dâwud, Sunan an-Nasâ'î, Sunan at-Tirmidzî, dan Sunan Ibnu Mâjah. Selain itu juga terdapat dalam al-Muwaththa' Imam Malik, Musnad Imam Ahmad, Shahîh Ibnu Hibbân, Sunan ad-Dârimî, al-Mu'jam ash-Shaghîr li ath-Thabrani, dan as-Sunan al-Kubrâ alBaihaqi. ${ }^{35}$

Hadits di atas terdapat dalam fatwa DSN-MUI tentang murâbahah dan salam. Salah satu tolok ukur kualitas hubungan sosial yang baik adalah bagaimana cara seseorang membayar utangnya kepada orang lain. Karena itu syariat memberikan ketentuan bahwa tatkala seseorang memiliki uang yang cukup untuk membayar tanggungan utang yang ia miliki, maka ia harus segera membayar utangnya kepada orang yang memberinya utang. Menunda bayar utang merupakan bentuk tindakan menzalimi orang lain. Makna riwayat di atas mengarah pada ketentuan haramnya menunda membayar utang tatkala seseorang sudah cukup secara finansial dan mampu untuk membayar. Berbeda ketika seseorang dalam keadaan tidak memiliki uang yang cukup, maka ia tidak tergolong dalam cakupan hadits di atas.

\section{Hadits Ahkam Muamalah ke-5}

\footnotetext{
34 al Bukhârî, Shahih al-Bukhârî, 3: 118; Muslim bin al Hallaj Abû al Hasan al Qusyairi an Naisabûri, Shahîh Muslim, vol. 3 (Beirut: Dâr Ihyâ at-Turats, t.t.), 1197; al Qazwînî, Sunan Ibnu Mâjah, 2: 803; as Sijistânî, Sunan Abû Dâwud, 3: 247; Abû 'Abdurrahman Ahmad bin Syu'aib bin 'Alî al Khurâsânî an Nasâ'î, Sunan anNasâ'î, vol. 7 (Aleppo: Maktab al-Mathbû'ât al-Islâmiyyah, 1986), 317; at Tirmidzî, Sunan at-Tirmidzî, 1998, 2: 591.

35 Mâlik bin Anas bin Mâlik bin Âmir al Ashbâhî al Madanî, al-Muwaththa', vol. 2 (Beirut: Dâr lhyâ' at-Turâts al- Ârab, 1985), 674; Abû 'Abdullah Ahmad bin Muhammad bin Hanbal bin Hilâl bin bin Asad asy Syaibânî, Musnad Ahmad, vol. 12 (Beirut: Muassasah ar-Risâlah, 2001), 505; at Tamîmî, Shahîh Ibnu Hibbân, 11: 435; Abû Muhammad 'Abdullah bin 'Abdurrahman bin al-Fadhl bin Bahram bin'Abdusshamad ad Dârimî, Sunan adDârimî, vol. 3 (Arab Saudi: Dâr al-Mughnî, 2000), 1684; al Baihaqî, as-Sunan al-Kubrâ, 6: 16; Abû al Qâsim Sulaimân bin Ahmad bin Ayyûb bin Muthair al Lakhmî asy Syâmî ath Thabrânî, al-Mu'jam ash-Shaghîr, vol. 1 (Beirut: al-Maktab al-islâmî Dâr 'Ûmâr, 1985), 386.
} 


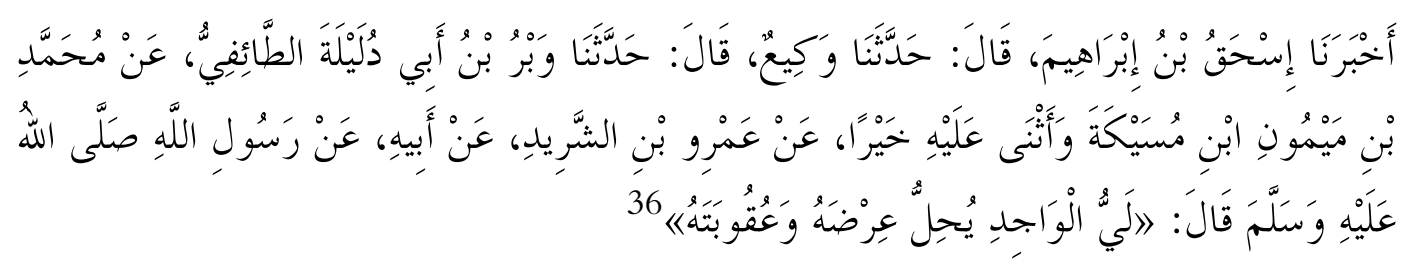

Telah mengabarkan kepada kami Ishaq bin Ibrahim telah menceritakan kepada kami Waki' telah menceritakan kepada kami Wabr bin Abu Dulailah Ath Thaify dari Muhammad bin Maimun bin Musaikah dan dia memujinya dengan kebaikan dari 'Amru bin Asy Syarid dari ayahnya dari Rasulullah shallallahu 'alaihi wasallam, beliau bersabda: "Menunda-nunda (pembayaran) yang dilakukan oleh orang mampu, menghalalkan harga diri dan pemberian sanksi kepadanya."

Hadits di atas terdapat dalam fatwa DSN-MUI tentang murâbahah dan salam. Hadits ini diriwayatkan oleh Imam an-Nasâ'î, Abû Dâwud, Ibnu Mâjah dan Ahmad sesuai dengan penjelasan riwayat dalam fatwa DSN-MUI. Selain itu juga ditemukan dalam riwayat Ibnu Hibbân dalam Shahîh Ibnu Hibbân, ath Thabrânî dalam mu'jam-nya (al-Mu'jam al-Ausath dan al-Mu'jam al-Kabîr), al Hakim dalam al-Mustadrak 'alâ ashShahîhain dan al Baihaqî dalam as-Sunan al-Kubrâ. Hadits ini dishahihkan oleh Ibnu Hibbân dalam kitab shahihnya dan al Hakim dalam kitab al-Mustadrak-nya. Adz Dzahabipun menilai demikian. Sedangkan Nâshiruddîn al Albânî dan Syu'aib al Arnauth menilai hadits ini hasan.

Berdasarkan hadits ke-4, apabila seorang debitur mampu tetapi menundanunda pembayaran maka itu termasuk berlaku zalim kepada kreditur. Maka hadits ke-5 selaras dan saling terkait dengan hadits ke-5. Maka debitur mampu yang menundanunda pembayaran dan/atau tidak mempunyai kemauan dan iktikad baik untuk membayar utangnya boleh dikenakan sanksi. Hadits ke-4 dan ke-5 ini pula yang menjadi dasar atau dalil hukum dalam pemberian sanksi oleh LKS kepada nasabah pembiayaan yang secara sengaja menunda pembayaran dari tempo yang sudah ditentukan padahal nasabah tersebut sebenarnya mampu secara finansial dalam membayar angsuran yang menjadi kewajibannya. Kebolehan pemberian sanksi oleh LKS ini diakomodir dalam Fatwa DSN-MUI No. 17/DSN-MUI/IX/2000 tentang Sanksi atas Nasabah Mampu yang Menunda-nunda Pembayaran. Sanksi ini didasarkan pada prinsip ta'zir, yaitu bertujuan agar nasabah lebih disiplin dalam melaksanakan kewajibannya.

\footnotetext{
${ }^{36}$ Abû 'Abdullah Ahmad bin Muhammad bin Hanbal bin Hilâl bin bin Asad asy Syaibânî, Musnad Ahmad, vol. 29 (Beirut: Muassasah ar-Risâlah, 2001), 465; al Qazwînî, Sunan Ibnu Mâjah, 2: 811; as Sijistânî, Sunan Abû Dâwud, 3: 313; an Nasâ'̂̀, Sunan an-Nasâ'î, 7: 316; Abû al Qâsim Sulaimân bin Ahmad bin Ayyûb bin Muthair al Lakhmî asy Syâmî ath Thabrânî, al-Mu'jam al-Ausath, vol. 3 (Kairo: Dâr al-Haramain, t.t.), 46; Abû al Qâsim Sulaimân bin Ahmad bin Ayyûb bin Muthair al Lakhmî asy Syâmî ath Thabrânî, al-Mu'jam al-Kabîr, vol. 7 (Kairo: Maktabah Ibnu Taimiyah, 1994), 318; an Naisâbûrî, al-Mustadrak 'alâ ash-Shahîhain, 1990, 4: 114; al Baihaqî, as-Sunan al-Kubrâ, 6: 85.
} 
Hadits Ahkam Muamalah ke-6

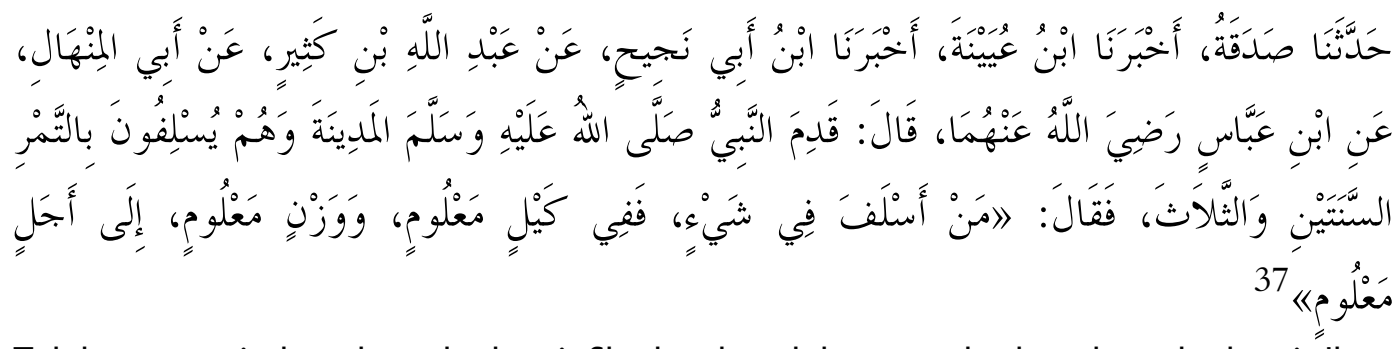

Telah menceritakan kepada kami Shadaqah telah mengabarkan kepada kami Ibnu 'Uyainah telah mengabarkan kepada kami Ibnu Abi Najih dari 'Abdullah bin Katsir dari Abu Al Minhal dari Ibnu 'Abbas radhiallahu 'anhuma berkata: Ketika Rasulullah shallallahu 'alaihi wasallam tiba di Madinah, mereka (penduduk Madinah) mempraktekan jual beli buah-buahan dengan sistim salaf, yaitu membayar dimuka dan diterima barangnya setelah kurun waktu dua atau tiga tahun kemudian, Maka Beliau bersabda: "Siapa yang mempraktekkan salaf (salam) dalam jual beli buah-buahan hendaklah dilakukannya dengan takaran yang diketahui dan timbangan yang diketahui, serta sampai waktu yang di ketahui".

Hadits di atas terdapat dalam fatwa DSN-MUI tentang jual beli salam. Teks hadits dalam fatwa tersebut merupakan riwayat Imam Bukhari. Hadits semakna dengan hadits ini juga ditemukan dalam riwayat Imam Muslim, Ibnu Mâjah, Abû Dâwud, at Tirmidzî, an Nasâ'î, ad Dâruquthnî dan al Baihaqî. ${ }^{38}$

Ibnu Hajar al-Asqalani dalam Kitab Fathul bari Syarah Shahih Bukhari berkenaan dengan hadits tentang jual beli salam menyebutkan jika para ulama sepakat bahwa jual beli salam disyariatkan, kecuali pendapat yang diriwayatkan dari Ibnu Musayyab..$^{39}$ Ibnu Baththal berkata,"Para ulama sepakat bahwa apabila barang yang dijual dengan sistem salam adalah barang yang ditakar atau ditimbang, maka saat transaksi harus menyebutkan takaran atau timbangan yang digunakan. Apabila barang itu bukan sesuatu yang ditakar atau ditimbang, maka harus disebutkan jumlahnya secara pasti." 40

Para ulama sepakat pula untuk mengetahui sifat barang yang akan diserahkan, yakni sifat yang membedakannya dari barang-barang lainnya. Seakan-akan bagian ini tidak disebutkan dalam hadits, karena mereka telah mempraktikkannya, sedangkan hadits itu memberi perhatian pada apa yang biasa mereka abaikan. ${ }^{41}$

Imam Nawawi dalam Syarah Shahih Muslim tentang hadits riwayat Imam Muslim berkenaan dengan jual beli salam menyebutkan dalam hadits tersebut terdapat

37 al Bukhârî, Shahih al-Bukhârî, 3: 85.

38 an Naisabûri, Shahîh Muslim, 3: 1226; al Qazwînî, Sunan Ibnu Mâjah, 2: 765; as Sijistânî, Sunan Abû Dâwud, 3: 275; at Tirmidzî, Sunan at-Tirmidzî, 1998, 2: 594; an Nasâ'î, Sunan an-Nasâ'̂̂, 7: 290; Abû al Hasan 'Alî bin Ahmad bin Mahdî bin Mas'ûd bin an Nu'mân bin Dînar al Baghdâdî ad Dâruquthnî, Sunan ad-Dâruquthnî, vol. 3 (Beirut: Muassasah ar-Risâlah, 2004), 380; al Baihaqî, as-Sunan al-Kubrâ, 6: 61.

39 Ibnu Hajar al 'Asqâlanî, Fathul Bâri, trans. oleh Amiruddin, vol. 13 (Jakarta: Pustaka Azzam, 2005$), 3$.

40 al 'Asqâlanî, 13: 9.

41 al 'Asqâlanî, 13: 9. 
keabsahan akad salam, syarat yang paling utama dalam akad salam ini adalah kuantitas dan kualitas barang yang dipesan harus jelas, baik terkait dengan takaran, timbangan, jumlah dan ukurannya. Jika yang dipesan itu berupa barang yang diukur, seperti pakaian maka harus jelas ukurannya. Jika berupa barang yang dihitung nominalnya seperti hewan maka hitungannya harus jelas. Jadi arti haditsnya adalah jika seseorang memesan barang yang ditakar, maka takarannya harus jelas, jika itu ditimbang maka timbangannya harus jelas, dan jika penyerahannya itu berjangka waktu maka jangka waktu itu harus jelas. ${ }^{42}$

Dengan dibolehkannya akad salam dengan berbagai ketentuan yang menjadi syarat kebasahannya, maka dibolehkan pula dilakukannya akad jual beli istishnâ', sebab kedua-duanya memiliki kesamaan yakni jual beli dengan penyerahan barang dikemudian hari atau tidak tunai, namun untuk istishnâ' lebih spesifik barang yang menjadi objek jual beli istishnâ' mengarah kepada objek yang dalam proses pembuatan atau perlu dibuat dulu semisal barang-barang manufaktur sebagai salah satu contohnya.

Wahbah az Zuhailî dalam al-Fiqh al-Islâmî wa Adillatuh menyebutkan bahwa kebolehan istishnâ' didasarkan pada dua metode nalar ijtihad yakni qiyâs dan istihsân. Para ulama (Imam Syafi'i, Imam Malik, dan Imam Ahmad) membolehkan akad istishnâ' ini dengan mengqiyaskannya dengan akad salam. Maka dalam akad istishnâ' disyaratkan seluruh syarat yang ada dalam akad salam. Sedangkan menurut Para ulama Hanafiyah berpedapat bahwa akad istishnâ' dibolehkan berdasarkan dalil istihsân yang ditunjukkan dengan kebiasaan masyarakat melakukan akad ini sepanjang masa tanpa ada yang mengingkarinya, sehingga menjadi ijma' tanpa ada yang menolaknya. ${ }^{43}$ Menggunakan konsep dalil seperti ini masuk dalam makna hadits:

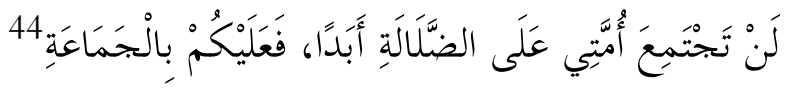
"Umatku tidak akan pernah bersepakat dalam kesesatan selamanya, maka ikutilah pada kesepakatan jamaah itu."

Ibnu Mas'ud pula berkata:

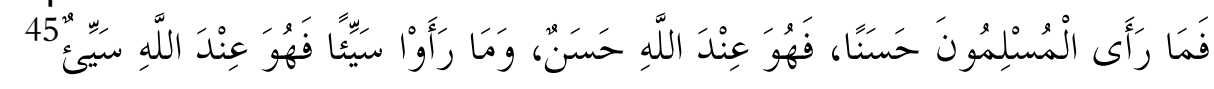

42 Imam an Nawawî, Syarah Shahîh Muslim, trans. oleh Darwis, Muhtadi, dan Fathoni Muhammad, vol. 7 (Jakarta: Daris Sunnah, 2010), 850.

43 az Zuhailî, al-Fiqh al-Islâmî wa Adillatuh, 4: 632.

${ }^{44}$ Abû al Qâsim Sulaimân bin Ahmad bin Ayyûb bin Muthair al Lakhmî asy Syâmî ath Thabrânî, al-Mu'jam alKabîr, vol. 12 (Kairo: Maktabah Ibnu Taimiyah, 1994), 447.

${ }^{45}$ Abû 'Abdullah Ahmad bin Muhammad bin Hanbal bin Hilâl bin bin Asad asy Syaibânî, Musnad Ahmad, vol. 6 (Beirut: Muassasah ar-Risâlah, 2001), 84; Abû al Qâsim Sulaimân bin Ahmad bin Ayyûb bin Muthair al Lakhmî asy Syâmî ath Thabrânî, al-Mu'jam al-Ausath, vol. 4 (Kairo: Dâr al-Haramain, t.t.), 58; Abû Bakar Ahmad 
“Maka apa yang dipandang kaum muslimin sebagai kebaikan, maka disisi Allah sebagai sebuah kebaikan. Dan apa yang dipandang kaum muslimin sebagai kejelekan, maka ia disisi Allah sebagai sebuah kejelekan."

\section{Hadits Ahkam Muamalah ke-7}

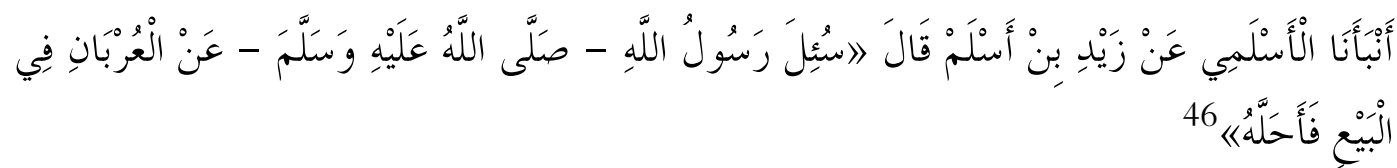

Al-Aslami memberi tahu kepada kami, dari Zaid bin Aslam, ia berkata, "Rasulullah SAW ditanya tentang "Urban (uang muka) dalam jual beli, maka beliau menghalalkannya."

Hadits di atas terdapat dalam fatwa DSN-MUI tentang Murâbahah. Hadits ini berbicara dengan legalitas uang muka atau dalam fikih disebut 'urbân atau 'urbûn. Hadits ini diriwayatkan oleh 'Abd ar-Razzâq dalam mushannaf-nya. Hadits yang serupa secara makna juga ditemukan dalam riwayat Ibnu Abî Syaibah dalam mushannaf-nya dengan redaksi:

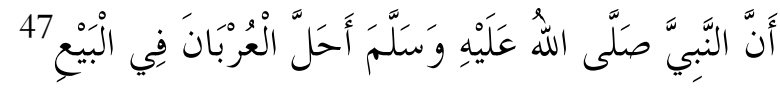

"Sesungguhnya Nabi SAW menghalalkan 'Urban (uang muka) dalam jual beli."

Hadits riwayat 'Abd ar-Razzâq tentang jual beli 'urbun ini menurut asySyaukâni haditsnya mursal, dalam sanadnya terdapat Ibrahim bin Abi Yahya dan ia dhaif. ${ }^{48}$ Pernyataan serupa tentang mursal-nya hadits riwayat 'Abd ar-Razzâq ini juga disampaikan oleh Ibnu Hajar al-Asqalânî dan Ibnu Mulqan. ${ }^{49}$

Mursal merupakan hadits yang hilang atau tidak disebutkan perawi dari golongan sahabat. Ciri hadits mursal adalah sebuah hadits yang disampaikan oleh tabi'in baik itu kibar at-tabi'in (tabi'in besar) maupun shighar at-tabi'in (tabi'in kecil)

bin al Husain bin 'Alî bin 'Abdullah bin Mûsa al Kharujardi al Baihaqî, al-l'tiqâd (Beirut: Dâr al-Âfaq alJadîdah, 1981), 322; Abû Bakar Ahmad bin al Husain bin 'Alî bin 'Abdullah bin Mûsa al Kharujardi al Baihaqî, al-Madkhal Ilâ as-Sunan al-Kubrâ (Kuwait: Dâr al-Khulafâ’ Li al-Kitâb al-Islâmî, t.t.), 114; Abû 'Abdullah Muhammad bin 'Abdullah al Hâkim an Naisâbûrî, al-Mustadrak 'alâ ash-Shahîhain, vol. 3 (Beirut: Dâr al-Kutub al-'Ilmiyah, 1990), 83; Abû Bakar Ahmad bin 'Amrû bin 'Abdul Khâliq bin Khalâd bin 'Ubaidillah al 'Atikî al Ma'ruf al Bazzâr, Musnad al-Bazzâr, vol. 5 (Madinah Munawwarah: Maktabah al-Ulûm wa al-Hukm, 1988), 212.

46 Jalâluddîn 'Abdurrahmân Abû Bakr as Suyûthî, Jâmi' al-Ahâdîts (wa Yasytamil 'Alâ Jam' al-Jawâmi' lî as Suyûthî wa al-Jâmi' al-Azhar wa Kunûz al-Haqâiq lî al Manâwî wa al-Fath al-Kabîr lî an-Nabhânî), vol. 40, t.t., h. 346; 'Alî bin 'Abd al Mâlik al Muttaqî al Hindî, Kanz al- 'Ummâl fî Sunan al-Aqwâl wa al-Af'âl, vol. 4 (Beirut: Muassasah ar-Risâlah, 1981), h. 155.

47 Abû Bakr bin Abî Syaibah, al-Mushannaf fî al-Ahâdîts wa al-Âtsâr, vol. 5 (Riyadh: Maktabah ar-Rasyad, 1989), h. 7.

48 Muhammad bin 'Alî bin Muhammad bin 'Abdullah asy Syaukânî, Nail al-Authâr, vol. 5 (Mesir: Dâr al-Hadîts, 1993), h. 182; Faishal bin 'Abdul 'Azîz bin Faishal bin Hamad al Mubârak, Bustan al-Âhbâr Mukhtashâr Nail al-Authâr, vol. 2 (Riyadh: Dâr Isybiliyâ, 1998), h. 15.

49 Abû al Fadhil Ahmad bin 'Alî bin Muhammad bin Ahmad bin Hajar al 'Asqalânî, At-Takhlîsh al-Habîr fî Takhrîj Ahâdîts ar-Râfi'î al-Kabîr, vol. 3 (Beirut: Dâr al-Kutub al-'llmiyah, 1998), h. 45; Ibn al Mulqan Sirâjuddîn Abû Hafsh 'Amr bin 'Alî bin Ahmad asy Syâfi'î al Mishrî, al-Badr al-Munîr fî Takhrîj al-Ahâdîts wa al-Autsâr al-Wâqi'ah fî asy-Syarh al-Kabîr, vol. 6 (Riyadh: Dâr al-Hijrah, 2004), h. 526. 
tanpa menyebutkan nama sahabat, dan langsung menyebut nama Nabi SAW. Jika ada tabiin yang menyebutkan hadits langsung dari Rasul, maka hadits tersebut adalah hadits mursal karena secara teknis seorang tabi'in tidak akan mendapatkan hadits tanpa sahabat. ${ }^{50}$

Para fukaha berbeda pendapat (ikhtilaf) dalam memandang status hukum jual beli dengan sistem uang muka (bai' al-'urbûn) apakah itu sah ataukah bathil dengan kata lain bertentangan dengan syariat Islam. ${ }^{51}$ Menurut Muhammad Shiddiq al-Jawi, memang sebagian ulama melarang jual beli dengan sistem uang muka berdasarkan hadist bahwa Nabi SAW melarang jual beli dengan uang muka (bai' al-'urbûn) (HR. Ahmad, Nasa'i, Ibnu Majah). Namun hadits ini ternyata lemah sehingga tidak dapat dijadikan hujjah atau dalil hukum pelarangan 'urbun. ${ }^{52}$

Menurut Yûsuf as Sabâtîn, uang muka dalam jual beli hukumnya boleh, karena ada riwayat dari Nafi' bin 'Abdul Harits, bahwasanya ia pernah membeli sebuah bangunan penjara dari Shafwan bin Umayyah untuk 'Umar bin Khattab dengan harga 4000 dirham. Apabila Umar ridha (bersedia membeli), maka transaksi jual beli terjadi (dilaksanakan), namun apabila umar tidak ridha (tidak jadi membeli), maka 400 Dirham sebagai uang muka menjadi milik Shafwan. ${ }^{53}$ Sedangkan menurut Wahbah az Zuhailî, jual beli dengan sistem uang muka (bai' al-'urbûn) itu status hukumnya sah dan halal dilakukan berdasarkan 'urf (adat kebiasaan atau tradisi berkembang di masyarakat yang tidak bertentangan dengan syariat Islam). Karena hadits-hadits yang diriwayatkan dalam masalah bai' al-urbun ini (dari pihak pro/yang membolehkan maupun kontra/yang melarang) tidak ada satupn yang shahih, maka dari itu tidak tepat untuk dijadikan hujjah atau dalil penetapan hukum. ${ }^{54}$

\section{Hadits Ahkam Muamalah ke-8}

50 Muhammad Alvin Nur Choironi, “Kajian Hadits Mursal dan Pembagiannya," 26 Maret 2019, https://islam.nu.or.id/post/read/104099/kajian-hadits-mursal-dan-pembagiannya.

51 Panji Adam, Maman Surahman, dan Popon Srisusilawati, “Analisis terhadap Fatwa Dewan Syariah Nasional (DSN) MUI Nomor 13 Tahun 2000 tentang Uang Muka dalam Murabahah," Prosiding SNaPP: Sosial, Ekonomi dan Humaniora 7, no. 3 (2017): h. 634.

52 Muhammad Shiddiq al Jawi, “Hukum Jual Beli Kredit (Cicilan) dan Uang Muka (Dp)," Konsultasi Islam (blog), 2 Februari 2009, https://konsultasi.wordpress.com/2009/02/02/hukum-jual-beli-kredit-cicilan-danuang-muka-dp/.

${ }^{53}$ Yûsuf Ahmad Mahmûd as Sabâtîn, al-Buyû' al-Qadîmah wa al-Mu'âshirah wa al-Bûrishât al-Mahliyah wa adDauliyah (Dâr al-Bayâraq, 2002), h. 162.

54 az Zuhailî, al-Fiqh al-Islâmî wa Adillatuh, 4:h. 450. 


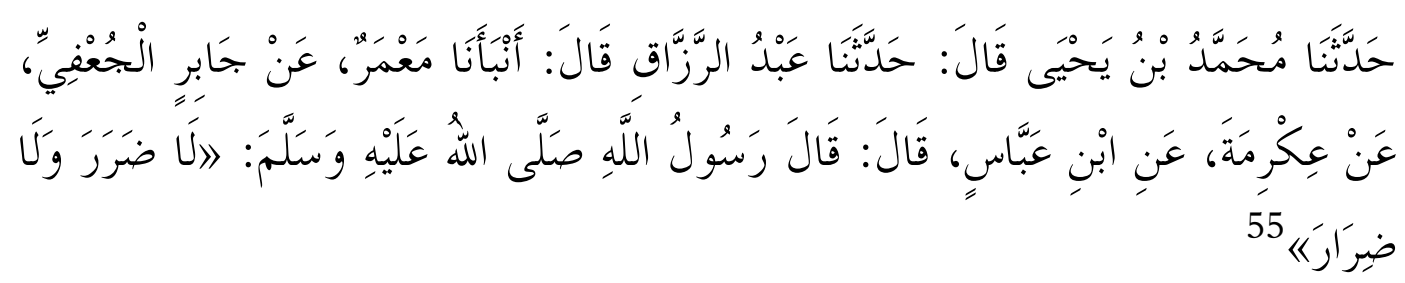

Telah menceritakan kepada kami Muhammad bin Yahya berkata, telah menceritakan kepada kami Abdurrazaq berkata, telah memberitakan kepada kami Ma'mar dari Jabir Al Ju'fi dari Ikrimah dari Ibnu Abbas, ia berkata, "Rasulullah SAW bersabda: "Tidak boleh membahayakan diri sendiri maupun orang lain."

Hadits di atas terdapat dalam fatwa DSN-MUI tentang istishnâ'. Hadits ini diriwayatkan oleh Imam Mâlik dalam al-Muwaththa', Ahmad dalam musnad-nya, Ibnu Majah dalam Sunan-nya, ad Dâruquthnî dalam Sunan-nya, ath- Thabrânî dalam mu'jam-nya, al-Hakim dalam al-Mustadrak dan al-Baihaqi dalam as-Sunan al-Kubrâ. Nâshiruddîn al Albânî menghukumi hadits ini shahih li ghairih. Dalam kaitannya dengan perjanjian syariah (akad), maka hadits ini menunjukkan keberadaan asas maslahat yakni dengan tidak bolehnya berlaku mudharat baik itu kemudharatan kepada diri sendiri maupun orang lain. Tujuan mengadakan akad pada hakikatnya adalah mencapai kemaslahatan bagi masing-masing pihak. Penjelasan maslahat dalam Islam meliputi dimensi kehidupan dunia dan akhirat. ${ }^{56}$

Kata maslahat secara etimologi merupakan akar kata shaluha (صلح). Kata ini digunakan untuk menunjukkan jika seseorang menjadi (berkeadaan atau tabiat) baik, tidak menyimpang, adil, shaleh atau jujur. Kata ini secara alternatif juga menunjukkan keadaan yang mengandung kebajikan-kebajikan tersebut. Maslahah berarti juga sebab, cara atau tujuan yang baik, yang bermanfaat. Penggunaan kata maslahat pada periode awal berarti kebaikan dan kemanfaatan. Secara umum maslahat biasa diberi muatan pengertian dengan ungkapan yang masyhur yaitu mengupayakan kemanfaatan dan menyingkirkan kemudharatan. ${ }^{57}$

\footnotetext{
55 al Madanî, al-Muwaththa', 2:h. 745; Abû 'Abdullah Ahmad bin Muhammad bin Hanbal bin Hilâl bin bin Asad asy Syaibânî, Musnad Ahmad, vol. 5 (Beirut: Muassasah ar-Risâlah, 2001), h. 55; al Qazwînî, Sunan Ibnu Mâjah, 2:h. 784; Abû al Hasan 'Alî bin Ahmad bin Mahdî bin Mas'ûd bin an Nu'mân bin Dînar al Baghdâdî ad Dâruquthnî, Sunan ad-Dâruquthnî, vol. 5 (Beirut: Muassasah ar-Risâlah, 2004), h. 407; Abû al Qâsim Sulaimân bin Ahmad bin Ayyûb bin Muthair al Lakhmî asy Syâmî ath Thabrânî, al-Mu'jam al-Ausath, vol. 1 (Kairo: Dâr al-Haramain, t.t.), h. 307; Abû 'Abdullah Muhammad bin 'Abdullah al Hâkim an Naisâbûrî, alMustadrak 'alâ ash-Shahîhain, vol. 2 (Beirut: Dâr al-Kutub al-'Ilmiyah, 1990), h. 66; al Baihaqî, as-Sunan alKubrâ, 6:h. 268.

56 Susanto, Hukum Kontrak Syariah, h. 44.

${ }^{57}$ Azhari, Qawaid Fiqhiyyah Muamalah, h. 187-188.
} 


\section{E. Kesimpulan}

Berdasarkan penelusuran penulis, maka hadits ahkam muamalah dalam tiga fatwa DSN-MUI yakni Fatwa DSN-MUI No. 04/DSN-MUI/IV/2000 tentang Murâbahah, Fatwa DSN-MUI No. 05/DSN-MUI/IV/2000 tentang Jual Beli Salam dan Fatwa DSN-MUI No.06/DSN-MUI/IV/2000 tentang Jual Beli Istishnâ', keseluruhannya berjumlah delapan hadits baik itu hadits yang dihadirkan untuk ketiga fatwa, dua fatwa saja maupun hanya ada pada satu fatwa dari ketiga jual beli tersebut. Dalam kajian yang penulis lakukan, maka dapat dikategorikan bahwa tiga hadits menunjukkan asas-asas dalam perjanjian syariah, yakni asas ar-ridha (hadits ke-1), asas al-ibâhah (hadits ke-3) dan asas al-mashlahah (hadits ke-8). Hadits ke-2 tentang keberkahan dalam jual beli tidak tunai (digolongkan hadits dhaif dalam kategori hadits majhul), hadits ke-4 dan 5 tentang pelarangan menunda pembayaran utang bagi yang mampu, hadits ke-6 mengenai legalitas jual beli salam, hadits ke-7 mengenai legalitas uang muka dalam jual beli (digolongkan hadits dhaif dalam kategori hadits mursal).

Murâbahah, salam dan istishnâ' merupakan aneka ragam bentuk jual beli yang saat ini dalam perkembangannya pada produk keuangan kontemporer dapat dilakukan baik secara personal maupun institusional. Maka Murâbahah, salam dan istishnâ' dalam kajian hadits ahkam, tidak ada hadits-hadits yang melarang, melainkan ketiga bentuk jual beli tersebut diperbolehkan, namun tetap dengan syarat-syarat dan ketentuan yang harus diikuti untuk menjaga legalitas atau keabsahan akadnya agar tidak tercambur baur dengan unsur-unsur terlarang dalam bermuamalah yang menjadikan haramnya suatu aktivitas muamalah.

\section{F. Referensi}

Adam, Panji, Maman Surahman, dan Popon Srisusilawati. "Analisis terhadap Fatwa Dewan Syariah Nasional (DSN) MUI Nomor 13 Tahun 2000 tentang Uang Muka dalam Murabahah." Prosiding SNaPP: Sosial, Ekonomi dan Humaniora 7, no. 3 (2017): 632-639.

Afrida, Yenti. “Analisis Pembiayaan Murabahah di Perbankan Syariah.” JEBI (Jurnal Ekonomi dan Bisnis Islam) 1, no. 2 (1 Desember 2016): 155-66. https: //doi.org/10.15548/jebi.v1i2.32.

Albânî, Muhammad Nâshiruddîn al. Irwâ' al-Ghalîl fî Takhrîj Ahâdîts Manâr as-Sabîl. Vol. 5. Beirut: al-Maktab al-Islâmî, 1985.

Anwar, Syamsul. Hukum Perjanjian Syariah: Studi tentang Teori Akad dalam Fikih Muamalat. Jakarta: RajaGrafindo Persada, 2010. 
Ash-Shawi, Shalah., dan Abdullah Al-Mushlih. Fiqih Ekonomi Keuangan Islam, Terj. Ma La yasa' at-Tajira Jahluhu. Jakarta: Darul Haq, 2008.

'Asqalânî, Abû al Fadhil Ahmad bin 'Alî bin Muhammad bin Ahmad bin Hajar al. AtTakhlîsh al-Habîr fî Takhrîj Ahâdîts ar-Râfi'î al-Kabîr. Vol. 3. Beirut: Dâr alKutub al-'Ilmiyah, 1998.

'Asqâlanî, Ibnu Hajar al. Fathul Bâri. Diterjemahkan oleh Amiruddin. Vol. 13. Jakarta: Pustaka Azzam, 2005.

Aswadi, “Islam sebagai Hasil Hubungan Sosial”, Jurnal Sosiologi Islam, Vol. 2, No.1, (April 2012).

Azhari, Fathurrahman. Qawaid Fiqhiyyah Muamalah. Banjarmasin: Lembaga Pengembangan Kualitas Umat, 2014.

Baihaqî, Abû Bakar Ahmad bin al Husain bin 'Alî bin 'Abdullah bin Mûsa al Kharujardi al. al-l'tiqâd. Beirut: Dâr al-Âfaq al-Jadîdah, 1981.

---. al-Madkhal Ilâ as-Sunan al-Kubrâ. Kuwait: Dâr al-Khulafâ' Li al-Kitâb al-Islâmî, t.t.

---. as-Sunan al-Kubrâ. Vol. 6. Beirut: Dâr al-Kutub al-`Ilmiyah, 2003.

Bassâm, Abû 'Abdurrahmân 'Abdullah bin 'Abdurrahmân bin Shâlih bin Hammad bin Muhammad bin Hammad al-. Taisîr al-'Allâm Syarah 'Umdah al-Ahkâm. Beirut: Maktabah at-Tâbi'în, 2006.

Bazzâr, Abû Bakar Ahmad bin 'Amrû bin 'Abdul Khâliq bin Khalâd bin 'Ubaidillah al 'Atikî al Ma'ruf al. Musnad al-Bazzâr. Vol. 5. Madinah Munawwarah: Maktabah al-Ulûm wa al-Hukm, 1988.

Bukhârî, Abû 'Abdullah Muhammad bin Ismâ'îl bin Ibrahim bin al Mughîrah bin Bardizbah al Ju'fi al. Shahih al-Bukhârî. Vol. 3. Beirut: Dâr Thauq an-Najah, 2001.

Chapra, M. Umer. Islam and The Economic Challenge. USA: The Islamic Foundation and The International Institute of Islamic Thought, 1996.

Choironi, Muhammad Alvin Nur. "Kajian Hadits Mursal dan Pembagiannya," 26 Maret 2019. https://islam.nu.or.id/post/read/104099/kajian-hadits-mursal-danpembagiannya.

Dârimî, Abû Muhammad 'Abdullah bin 'Abdurrahman bin al-Fadhl bin Bahram bin'Abdusshamad ad. Sunan ad-Dârimî. Vol. 3. Arab Saudi: Dâr al-Mughnî, 2000.

Dâruquthnî, Abû al Hasan 'Alî bin Ahmad bin Mahdî bin Mas'ûd bin an Nu'mân bin Dînar al Baghdâdî ad. Sunan ad-Dâruquthnî. Vol. 3. Beirut: Muassasah ar-Risâlah, 2004.

---. Sunan ad-Dâruquthnî. Vol. 5. Beirut: Muassasah ar-Risâlah, 2004.

Dewan Syariah Nasional (DSN) Majelis Ulama Indonesia (MUI) dalam https://dsnmui.or.id/. 
Hading, Hading. “Hadis Ḍa'îf (Sebab-Sebab Ke-Ḍa'îf-an dan Ke-Ḥujjah-annya Menurut Ulama Ahli Hadis)." Shaut al Arabiyyah 5, no. 1 (2017): 15-38.

Hamûd, Sâmî Hasan Ahmad. Tathwîr al-A'mâl al-Mashrafiyyah bi Mâ Yattafiq asySyar'iyyah al-Islâmiyyah. Dubai: Mathba'ah asy-Syarq wa Maktabatihâ, 1982.

Hindî, 'Alî bin 'Abd al Mâlik al Muttaqî al. Kanz al-'Ummâl fî Sunan al-Aqwâl wa alAf’âl. Vol. 4. Beirut: Muassasah ar-Risâlah, 1981.

Husainî, Taqiyuddîn Abû Bakr bin Muhammad al Hushnî al. Kifâyah al-Akhyâr. Damaskus: Dâr al-Basyâir, 2001.

Jawi, Muhammad Shiddiq al. "Hukum Jual Beli Kredit (Cicilan) dan Uang Muka (Dp)." $\begin{array}{lllll}\text { Konsultasi Islam } & \text { (blog), } & 2 & \text { Februari }\end{array}$ https: //konsultasi.wordpress.com/2009/02/02/hukum-jual-beli-kredit-cicilandan-uang-muka-dp/.

Karim, Adiwarman A. Bank Islam: Analisis Fiqih dan Keuangan. Jakarta: RajaGrafindo Persada, 2008.

Kholis, Mohammad Maulana Nur. "Hukum Mengamalkan Hadist Dhaif Dalam Fadhail A'mal: Studi Teoritis Dan Praktis." Al-Tsiqoh: Jurnal Ekonomi Dan Dakwah Islam 1, no. 2 (2016): 26-39.

Madanî, Mâlik bin Anas bin Mâlik bin Âmir al Ashbâhî al. al-Muwaththa'. Vol. 2. Beirut: Dâr lhyâ' at-Turâts al- Ârab, 1985.

Mardani. Fiqih Ekonomi Syariah: Fiqih Muamalah. Jakarta: Kencana, 2012.

Mishrî, Ibn al Mulqan Sirâjuddîn Abû Hafsh 'Amr bin 'Alî bin Ahmad asy Syâfi'î al. alBadr al-Munîr fî̀ Takhrîj al-Ahâdîts wa al-Autsâr al-Wâqi'ah fî asy-Syarh alKabîr. Vol. 6. Riyadh: Dâr al-Hijrah, 2004.

Mubârak, Faishal bin 'Abdul 'Azîz bin Faishal bin Hamad al. Bustan al-Âhbâr Mukhtashâr Nail al-Authâr. Vol. 2. Riyadh: Dâr Isybiliyâ, 1998.

Naisâbûrî, Abû 'Abdullah Muhammad bin 'Abdullah al Hâkim an. al-Mustadrak 'alâ ashShahîhain. Vol. 4. Beirut: Dâr al-Kutub al-'Ilmiyah, 1990.

---. al-Mustadrak 'alâ ash-Shahîhain. Vol. 3. Beirut: Dâr al-Kutub al-'Ilmiyah, 1990.

---. al-Mustadrak 'alâ ash-Shahîhain. Vol. 2. Beirut: Dâr al-Kutub al-'Ilmiyah, 1990.

Naisabûri, Muslim bin al Hallaj Abû al Hasan al Qusyairi an. Shahîh Muslim. Vol. 3. Beirut: Dâr lhyâ at-Turats, t.t.

Nasâ'î, Abû 'Abdurrahman Ahmad bin Syu'aib bin 'Alî al Khurâsânî an. Sunan an-Nasâ'î. Vol. 7. Aleppo: Maktab al-Mathbû’ât al-Islâmiyyah, 1986.

Nawawî, Imam an. Syarah Shahîh Muslim. Diterjemahkan oleh Darwis, Muhtadi, dan Fathoni Muhammad. Vol. 7. Jakarta: Daris Sunnah, 2010.

Pusat Pengkajian Hukum Islam dan Masyarakat Madani. Kompilasi Hukum Ekonomi Syariah. Depok: Kencana, 2009. 
Qaradhâwî, Yûsuf al. al-Qawâ'id al-Hâkimah li Fiqh al-Mu'âmalât. Kairo: Dâr asySyurûq, 2010.

Qazwînî, Abû Abdullah Muhammad Bin Yazîd bin Mâjah al. Sunan Ibnu Mâjah. Vol. 2. Kairo: Dâr al-Ihya' al-Kutub al-'Arabiyah, t.t.

Rasjid, Sulaiman. Fiqh Islam. Bandung: Sinar Baru Algesindo, 1998.

Sabâtîn, Yûsuf Ahmad Mahmûd as. al-Buyû' al-Qadîmah wa al-Mu'âshirah wa alBûrishât al-Mahliyah wa ad-Dauliyah. Dâr al-Bayâraq, 2002.

Sâbiq, Sayyid. Fiqh as-Sunnah. Vol. 3. Kairo: al-Fath lil l’lâm al-'Arabî, 2004.

Sijistânî, Abû Dâwud Sulaimân bin al Asy'ats bin Ishâq bin Basyîr bin Syidâd bin 'Amrû al-Azdî as. Sunan Abû Dâwud. Vol. 3. Beirut: Maktabah al-'Ashriyah, t.t.

Susanto, Burhanuddin. Hukum Kontrak Syariah. Yogyakarta: BPFE, 2009.

Suyûthî, Jalâluddîn 'Abdurrahmân Abû Bakr as. Jâmi' al-Ahâdîts (wa Yasytamil 'Alâ Jam' al-Jawâmi' lî as Suyûthî wa al-Jâmi' al-Azhar wa Kunûz al-Haqâiq lî al Manâwî wa al-Fath al-Kabîr lî an-Nabhânî). Vol. 40, t.t.

Syaibah, Abû Bakr bin Abî. al-Mushannaf fî al-Ahâdîts wa al-Âtsâr. Vol. 5. Riyadh: Maktabah ar-Rasyad, 1989.

Syaibânî, Abû 'Abdullah Ahmad bin Muhammad bin Hanbal bin Hilâl bin bin Asad asy. Musnad Ahmad. Vol. 14. Beirut: Muassasah ar-Risâlah, 2001.

---. Musnad Ahmad. Vol. 12. Beirut: Muassasah ar-Risâlah, 2001.

---. Musnad Ahmad. Vol. 29. Beirut: Muassasah ar-Risâlah, 2001.

---. Musnad Ahmad. Vol. 6. Beirut: Muassasah ar-Risâlah, 2001.

---. Musnad Ahmad. Vol. 5. Beirut: Muassasah ar-Risâlah, 2001.

Syaukânî, Muhammad bin 'Alî bin Muhammad bin 'Abdullah asy. Nail al-Authâr. Vol. 5. Mesir: Dâr al-Hadîts, 1993.

Tamîmî, Abû Hâtim Muhammad bin Hibbân bin Ahmad bin Hibbân bin Mu'adz bin Ma'bad at. Shahîh Ibnu Hibbân. Vol. 11. Beirut: Muassasah ar-Risâlah, 1993.

Thabrânî, Abû al Qâsim Sulaimân bin Ahmad bin Ayyûb bin Muthair al Lakhmî asy Syâmî ath. al-Mu'jam al-Ausath. Vol. 3. Kairo: Dâr al-Haramain, t.t.

---. al-Mu'jam al-Ausath. Vol. 4. Kairo: Dâr al-Haramain, t.t.

---. al-Mu'jam al-Ausath. Vol. 1. Kairo: Dâr al-Haramain, t.t.

---. al-Mu'jam al-Kabîr. Vol. 7. Kairo: Maktabah Ibnu Taimiyah, 1994.

---. al-Mu'jam al-Kabîr. Vol. 12. Kairo: Maktabah Ibnu Taimiyah, 1994.

---. al-Mu'jam ash-Shaghîr. Vol. 1. Beirut: al-Maktab al-islâmî Dâr 'Ûmâr, 1985.

Tirmidzî, Abû 'îsâ Muhammad bin 'îsâ bin Saurah bin Mûsa bin adh Dhahâk at. Sunan at-Tirmidzî. Vol. 2. Beirut: Dar al-Gharb al-Islami, 1998. 
---. Sunan at-Tirmidzî. Vol. 3. Beirut: Dar al-Gharb al-Islami, 1998.

Widiana, Widiana, dan Arna Asna Annisa. "Menilik Urgensi Penerapan Pembiayaan Akad Salam pada Bidang Pertanian di Lembaga Keuangan Syariah di Indonesia." Muqtasid: Jurnal Ekonomi dan Perbankan Syariah 8, no. 2 (2017): 88-101. https: //doi.org/10.18326/muqtasid.v8i2.88-101.

Zein, M. Ma'shum. Ilmu Memahami Hadits Nabi: Cara Praktis Menguasai Ulumul Hadits dan Musthalah Hadits. Yogyakarta: Pustaka Pesantren, 2016.

Zuhailî, Wahbah az. al-Fiqh al-Islâmî wa Adillatuh. Vol. 4. Damaskus: Dâr al-Fikr, 1985. 